\title{
School Engagement Predictors for Indonesian Islamic Student
}

\author{
Teguh Fachmi ${ }^{1}$, Rena Latifa ${ }^{2}$, Ahmad Habibi Syahid $^{3}$, Kheryadi $^{4, *}$, Hidayatullah ${ }^{5}$, \\ Reza Rachmadtullah ${ }^{6}$
}

\begin{abstract}
${ }^{1}$ Department of Early Childhood Islamic Education, FTK, Sultan Maulana Hasanuddin State Islamic University, Banten, Indonesia
${ }^{2}$ Department of Psychology, Faculty of Psychology, Syarif Hidayatullah State Islamic University, Jakarta, Indonesia

${ }^{3}$ Department of Arabic Literature, FUDA, Sultan Maulana Hasanuddin State Islamic University, Banten, Indonesia

${ }^{4}$ Department of English Education, FTK, Sultan Maulana Hasanuddin State Islamic University, Banten, Indonesia

${ }^{5}$ Department of Islamic Education, FTK, Sultan Maulana Hasanuddin State Islamic University, Banten, Indonesia

${ }^{6}$ Department of Elementary School Teacher Education, FKIP, PGRI Adi Buana University, Surabaya, Indonesia
\end{abstract}

Received August 6, 2019; Revised September 17, 2019; Accepted September 262019

Copyright $\bigcirc 2019$ by authors, all rights reserved. Authors agree that this article remains permanently open access under the terms of the Creative Commons Attribution License 4.0 International License

\begin{abstract}
Throughout Indonesia, at all levels of higher education and schools, an increased rate of boredom, dropout risk, decreased involvement and low academic achievement is directly related to low school engagement. The Education of Islamic School (Pesantren) is known as one of the highest risks of disengages. The 2015 PISA study results for engagement and motivation in learning ranked Indonesia in the $62 \mathrm{nd}$ position out of a possible 70 . Thus, Indonesia is perceived as having a low level of learning engagement. This study examines the effect of self-efficacy, self-concept, and social support regarding school engagement. The study sample included 213 Senior High School students from the Assa'adah Islamic Boarding School (Pesantren). The sample was taken using a simple random sampling technique. Multiple regression analysis was used to analyze the data. Study results show that there is a significantly positive effect when self-efficacy, self-concept, and social support are able to influence school engagement. The significant variance in the proportion of school engagement was $97.9 \%$ for all independent variables and the rest was explained by the residual. The Results for minor hypotheses shows that eight variables significantly affected school engagement namely initiative, persistence, effort, self-evaluation, attachment, guidance, a reassurance of worth and social integration. Other variables had no significant effect on school engagement.
\end{abstract}

Keywords Islamic Boarding School, School Engagement, Self-efficacy, Self-concept, Social Support

\section{Introduction}

Student engagement is compulsory in the learning process[1]. Students, who have high engagement in school, will feel more comfortable and eager when participating in various learning activities. A number of studies have shown a positive relationship between student engagement and academic success [1]. Students who engage in learning activities, especially in the classroom, are much more likely to have better achievement results compared to students, who are not involved with the activity [2]. Furrer and Skinner (2003) added that school engagement is a plausible predictor of long-term academic achievement and for completion of study. So the level of engagement or involvement of learning becomes one of non-academic factors that can affect the success of learning [3].

Fredricks, Blumenfeld, and Paris (2004) defined school engagement as the active participation of students, such as striving, struggling, concentrating, paying attention, obeying rules, and using self-regulation strategies in learning activities which is followed by positive emotions. School engagement encompassing three dimensions, namely behavioral engagement, emotional engagement, and cognitive engagement. School engagement describes how students' feelings, behaviors and thoughts about their experiences at school. Students' engagement of the school in the behavior matter, cognitive matter, and emotion matter has a positive relationship to learning achievement and completion of the study. Thus, it becomes important to learn, because it relates to the behavior of student in following the learning activities, which will ultimately affect the achievement of academic achievement, and completion of the study [4]. 
Teaching and learning process can face various problems, both internal and external. Problem that arise when learning and teaching activities will have serious consequences if not handled properly. One example of problem that student may experience is lack of involvement and participation in learning, low motivation, boredom, academic discontent, and juvenile delinquency. Those problems will lead students to be at risk of dropping out of school, unable to complete studies and have low achievement results.

Increased dropout risk, boredom, decreased involvement and low academic achievement, which is caused by low school engagement, can be found at all levels of education and schools in Indonesia. The results of the 2015 PISA study on engagement and motivation in learning put Indonesia in the $62 \mathrm{nd}$ position of the 70 countries that followed. This result indicates that Indonesia is still a country with a low level of participation in learning. So it becomes very important to do research on school engagement.

One of phenomenon concerning low learning engagement and high risk of drop out were occurred in Islamic boarding school, which is known with his an integrated Islamic education system, this concept of education is obligated student to live in boarding school. Student not only gets some learning materials in the classroom, but also gets religious guidance and disciplinary habituation carried out through various activities. High disciplines, mastery of science, the implementation of Islamic values are special feature of Islamic education system (pesantren). Because students are required to live in boarding or dormitories, it is become an important reason why students should have good engagement, they should adapt and participate in various activities with a passion, feelings of affection followed by positive emotions, so they can have a comfortable to live in pesantren, and impacted on completion of their studies.

In fact, not all students are able to follow the rules of pesantren, but parts of them are able to follow the rules and successfully graduate for six years of their education: consisting of three years of junior high school and three years of senior high school. However, also there are students who cannot complete the six-year education, and then resign to other school. From the admission data of new students and data of graduated students in the last ten years of Assa'adah Islamic Boarding School Serang-Banten, the researchers found the gap between the number of students' admission and graduates in each year, where the number of graduates are not equal to the number at the beginning of admission, the number of graduate is only $70 \%$ and the remaining $30 \%$ cannot complete their learning in pesantren[5].

Many factors can explain why this phenomenon occurs, one of which can be caused by low school engagement students, thus impact of feelings unhappy and finally they resign. Then, the variety of pesantren activities with various forms of educational activities, which is not only requires students to maximize intellectual ability, but also requires students to be able to live in boarding which requires a person to have independence, self-adjustment, self-regulation and social skills. Based on a recent research literature review focusing on school engagement variables, the results generally show that the causes of school engagement can be divided into two factors, namely internal factors and external factors.

Internal factors are related to the influence of self-variables, such as motivation, self-concept, and self-efficacy. Caraway, Tucker, Reinke, Hall (2003) suggest that self-variables or psychological variables derived from within individuals which have a direct influence on student involvement, self-variables also directly affect one's engagement level._Furthermore, it is argued that self-efficacy is a basic key concept as a self-variable that can affect motivation in achievement[6]. Goetz et al. (2010) added in the results of his research that self-efficacy affects the way of thinking, acting and emotion directly. His research proves that there is a positive relationship between self-efficacy and school engagement, self-concept and student emotional involvement. Then the concept of self with regards to the perception of school and control during the learning process, so that it can affect school engagement [7].

While external factors related to the contextual variables that come from outside the student self. Caraway, Tucker, Reinke, Hall (2003) reveals that contextual variables are concerned with social support, such as family support, peer support, school environments or peer support [6]. You (2011) outlines that the importance of social support, such as peer support, can influence the development of adolescent behavior, and the acceptance of peer environments is also a key measure of positive or negative experiences in school, acceptance and support from peers can provide feelings of motivation and help students understand the importance of pursuing academic success. Stipek (2012) adds that when students feel socially getting support from teachers and peers they will feel more focus on mastering the material and tasks [8]. Then, Dotterer and Lowe (2011) stated that if student have a negative relationship with teachers, it is likely to have problems with engagement and academic achievement [9].

The dynamics of school engagement phenomenon above provides insight to researchers that school engagement can be influenced by several psychological factors, such as internal factors and external factors. Internal factor related to self- variables such as self-efficacy, self-concept. While external factors related to contextual variables such as social support. According to Caraway, Tucker, Reinke, Hall (2003) that contextual variables and self-variables often have complex relationships with each other and often have very close relationships[6]. Based on the background that has been described, the researchers consider the need for further research on psychological factors that can affect 
school engagement. Furthermore, to realize it, the researchers will conduct research with the title "School Engagement Predictors for Indonesian Islamic Student with focus to the effect of self- efficacy, self-concept, and social support to school engagement of senior high school students of Pesantren Assa'adah".

\section{Materials and Methods}

\subsection{School Engagement}

Frederick, Blumenfeld and Paris (2004) formulated school engagement into three dimensions, namely behavioral engagement, emotional engagement and cognitive engagement, so that school engagement is defined as the active participation of students such as struggling, striving, concentrating, paying attention, obeying the rules, and using self-regulation strategies in learning activities which is accompanied by positive emotions. Basically, many factors that can affect school engagement and depend on the context of study. The following researchers explain about some factors that can affect school engagement. There are two big factors that can influence school engagement, which is divided into two factors, first is internal factor, which related to self-variable such as self-efficacy, and self-concept. Second is an external factor, which is associated with contextual variables such as social support [4].

\subsection{Self-efficacy}

Self-efficacy can influence the way of thinking, acting and emotion directly [7]. Several studies have shown that there is an influence of self-efficacy on school engagement, one of research was conducted by Caraway, Tucker, Reinke and Hall (2003) revealed that self-efficacy has a positive relationship to school engagement. The results of his research suggest that the more confident a person feels about his ability, the more he or she will have good grades and more active involvement in some aspects of the school [6].

In this study, the authors use the definition and dimensions of self-efficacy from Bosscher \& Smit (1998), which explains that self-efficacy is a person's belief in understanding his ability to organize and implement certain behaviors necessary to produce the achievement of the task. The reason why the author uses the definitions and dimensions expressed by Bosscher and Smit (1998), because the three dimensions expressed by Bosscher and Smit namely initiative, Effort, and Persistence are suitable for measuring the efficacy of students in pesantren, where the initiative dimension is a person's willingness to behave first, this dimension refers to the behavior of individuals to be ready to face a various situation, then dimensions of effort in the form of a willingness to try in doing something perfectly, it is also related to the belief of someone in facing many challenges, and the dimension of persistence is associated with perseverance in facing adversity. The three dimensions will be able to describe how the level of student efficacy in pesantren[10].

The level of self-efficacy determines someone's ability to complete tasks, including the ability to choose which tasks to complete first, the seriousness of the effort, persistence, and enthusiasm for the task, which is followed by positive feelings. Self-efficacy then determines whether will we exhibit certain behaviors (initiative), how strongly can we survive while facing difficulties or failures (persistence), and how is success or failure in a particular task affects our behavior in the future.

\subsection{Self-concept}

Self-concept is an important construct in social science and has long been studied intensively by scientists, because it has a positive impact on several things, especially in the field of education. Self-concept also has a correlation with some constructs, such as, intelligence, interpersonal relationships, and social-skills [11]. Although the measurement and definition of self-concept is still debatable, the researchers agree that the concept of self is one's view of him [12]. As an individual interacts with his environment, the individual evaluates his own behavior and develops a personal description of him called self-evaluation [13].

The concept of self as one of the internal variables which can influence one's behavior, some researches have stated that there was a positive relationship between self-concept and school engagement. One study was conducted by Singh, Chang, and Dika (2010) to 1,157 secondary school students in three western regions of Virginia United States [14]. The results of their study note that the concept of self is closely related to the sense of ownership of the school (school belonging), the feeling of happiness while learning (enjoyment of learning), and then increase the involvement in learning (school engagement). Self-concept is also known as one of variables that have strong influence on student persistence in completing the task. Conclusions from this research that self-concept influence school engagement and also can improve learning achievement with different quantity [14].

Based on the description of self-concept above, this research use self-concept definition based on Campbell et all (1996) where self-concept is defined as cognitive scheme; organized knowledge structures contains the nature of values, episodic memories, and semantic memories of self and control of relevant self-processing information, the content of self-concept and structure can be divided into two dimensions: self-knowledge and self-evaluation [15].

\subsection{Social Support}

Some earlier researchers argued that school engagement 
may decline as social environment changes or move to higher levels of schooling, reduced interaction with teachers, and changes in social support from teachers, friends and parents[16]. You explain that the importance of social support, such as peer support, can influence the development of adolescent behavior, in addition to the acceptance of peer environments is also a key measure of positive or negative experiences in school, peer acceptance and support can also provide feeling motivated and help students understand the importance of pursuing academic success.

Several studies have suggested that social support has an influence on school engagement, one of the studies conducted by Wang and Eccles (2010) to 1,792 secondary school sample, this research is aimed for identifying the effect of social support on the three dimensions of school engagement in the middle to upper secondary level, the results of their research noted that students who have high social support tend to have good adaptation and high achievement motivation, social support which is derived from teachers can also foster feelings of love to school (school belonging) and improve achievement[17], while students who have positive social support of peers have a high degree of engagement both emotion and behavior[18].

Based on the description of social support above, in this study the researchers uses the definition of social support according to Cutrona \& Russell which, explain that social support is a process of relationship formed from individuals who feel loved and appreciated, the dimensions contained in this social support include attachment, social integration, reassurance of worth, reliable alliance, guidance, opportunity for nurturance [19].

\subsection{Research Hypothesis}

Major Hypothesis (Ha): There is a significant influence of self-efficacy (initiative, effort, persistence), self-concept (self-knowledge, self-evaluation), and social support (attachment, social integration, reassurance of worth, reliable alliance, guidance, and opportunity for nurturance) to school engagement of Senior High School of Pesantren Assa'adah. Further research hypotheses are derived into minor hypotheses to be tested in statistical analysis.

\subsection{Research Method}

This research uses quantitative approach with multiple regression analysis. The populations in this study are students of Pesantren Assa'adah male (Santriwan) and female (Santriwati) at the age of 15-17 years who are living in the boarding. Furthermore, researchers examined a sample of 213 people from the population taken by probability sampling (simple random sampling). Data collection was conducted on 22-23 April 2017. The scale used to measure school engagement is the adaptation of School Engagement Measurement (SEM) developed by
Jennifer Frederick and Phylis Blumenfield

The scale uses to measure self-efficacy is the scale of General Self Efficacy Scale (GSES-12) that has been revised from the previous General Self-Efficacy Scale, so 5 of the 17 items have been excluded from the GSES, due to ambiguous and low-correlated words. This instrument consists of 12 items, after validity test results obtained 12 items are valid. The scale uses to measure self-concept is Self-Concept Clarity Scale (SCCS) which is developed by Campbell, at.al, (1996).

This instrument consists of 12 items, after validity test, the result 12 items are valid. The scale uses to measure social support is The Social Provision Scale which is developed by Cutrona. This instrument consists of 24 items, after validity test, 24 items are valid [19].

\subsubsection{Research Design}

This research uses quantitative approach with multiple regression analysis. Multiple regression analysis method is a method to predict and test the significance of the influence of a set of independent variables (IV) on a dependent variable (DV). The multiple regression analysis used in this study aims to find out the magnitude of the influence of the eleven independent variables (IV) on school engagement (DV).

\subsubsection{Research Sample}

The populations in this study are 413 students of Assa'adah Islamic Boarding School male and female at the age of 15-17 years who are living in the dormitory. Furthermore, researchers examined a sample of 213 people from the population taken by probability sampling (simple random sampling). This method is used so that each member of the population has the same opportunity to be elected as a sample member.

\subsubsection{Research Instrument and Procedures}

Research data were collected by using research instruments scales adapted from experts, the research data collection instrument consisted of three parts. The first part consists of the respondent's identity and demographic questions covering current gender, age, and class. The second part contains an explanation of the instrument filling instructions and scale statements namely the scale of school engagement, the scale of self-efficacy, the scale of self-concept, and the scale of social support. In this study, data collection techniques using a Likert scale model, scale are a statement of agreement or disagreement. The answer to each item of this instrument ranges from the highest (very positive) to the lowest (very negative). The whole scale is measured through four response categories namely "Strongly Agree" (SA), "Agree" (A), "Disagree" (D), and "Strongly Disagree" (SDS). This is done to avoid central tendency or to avoid neutral responses.

The scale used to measure school engagement is the adaptation of School Engagement Measurement (SEM) it 
was developed by Jennifer Frederick and Phylis Blumenfield (2005). This instrument consists of 15 items, after validity test, 15 items are valid. [19]

The scale used to measure self-efficacy is the scale of General Self Efficacy Scale (GSES-12) that has been revised from the previous General Self-Efficacy Scale, so, 5 of the 17 items have been excluded from the GSES, due to ambiguous and low-correlated words. This instrument consists of 12 items, after validity test results obtained 12 items are valid.

The scale used to measure self-concept is Self-Concept Clarity Scale (SCCS), which is developed by Campbell, at.al, (1996). This instrument consists of 12 items, after validity test, the result 12 items are valid.

The scale used to measure social support is The Social Provision Scale, which is developed by Cutrona (1987). This instrument consists of 24 items, after validity test, 24 items are valid.

\subsubsection{Data Analysis}

Multiple regression analysis is one of the statistical techniques that are useful for examining and modeling relationships between variables. As explained above that in this regression it will be seen whether the independent variable significantly influences the dependent variable. Then also seen the amount of $R$ square to find out what percentage (\%) of the dependent variable is explained by the independent variable, and then see whether or not the regression coefficient is significant for each independent variable. To assess whether the resulting regression model is the most appropriate model (has the smallest error), it takes some testing and analysis as follows; $R^{2}$ (coefficient of multiple determinants), through this multiple regression a $R$ value will be obtained, which is the coefficient of multiple correlation between school engagement on self-efficacy, self-concept and social support. Then the magnitude of the possibilities caused by the factors mentioned earlier is shown by the coefficient of multiple determinants or $R^{2}$. The $R^{2}$ functions are used to see the proportion of variance in school engagement that is influenced by self-efficacy, self-concept, and social support.

\section{Results}

From the result of multiple regressions analysis obtained R-Square equal to 0.979 or $97.9 \%$ means that the proportion of variance from school engagement explained by all independent variable is $97.9 \%$ while the remaining $2.1 \%$ is influenced by other variables not included in this research.

Based on table 1, it is known that $(\mathrm{P}<0.05)$ which means that the null hypothesis, which states no significant influence of all independent variables, is rejected. This means that there is a significant influence of self-efficacy variables (initiative, effort, and persistence), self-concept (self-knowledge, self-evaluation), social support (attachment, social integration, reassurance of worth, reliability alliance, guidance and opportunity for nurturance) to school engagement of Senior High School of Pesantren Assa'adah. The next step is to examine the regression coefficient of each independent variable (IV). The coefficient can be seen in table 2 below.

Table 1. ANOVA School Engagement

\begin{tabular}{|c|c|c|c|c|c|c|}
\hline \multicolumn{9}{|c|}{ ANOVAa, b } \\
\hline \multirow{2}{*}{ Model } & Sum of Squares & df & Mean Square & F & Sig. \\
\cline { 2 - 8 } & Regression & 9260.581 & 11 & 841.871 & 836.652 & $.000 \mathrm{c}$ \\
\cline { 2 - 7 } & Residual & 202.254 & 201 & 1.006 & & \\
\cline { 2 - 7 } & Total & 9462.834 & 212 & & & \\
\hline
\end{tabular}

Dependent Variable: School Engagement

Weighted Least Squares Regression - Weighted by Bobot

Predictors: (Constant), initiative, effort, persistence, pengetahuan diri, evaluasi diri, attachment, social integration, reassurance of worth, reliable alliance, guidance dan opportunity for nurturance. 
Table 2. Regression coefficient

\begin{tabular}{|c|c|c|c|c|c|}
\hline \multirow{2}{*}{ Model } & \multicolumn{2}{|c|}{ Unstandardized Coefficients } & \multirow{2}{*}{$\begin{array}{c}\text { Standardized Coefficients } \\
\text { Beta }\end{array}$} & \multirow{3}{*}{$\begin{array}{c}t \\
27.897\end{array}$} & \multirow{3}{*}{$\begin{array}{l}\text { Sig. } \\
.000\end{array}$} \\
\hline & \multirow{2}{*}{$\begin{array}{c}\text { B } \\
24.849\end{array}$} & \multirow{2}{*}{$\begin{array}{c}\text { Std. Error } \\
.891 \\
\end{array}$} & & & \\
\hline (Constant) & & & & & \\
\hline Initiative & .152 & .013 & .309 & 11.663 & .000 \\
\hline Persistence & .149 & .018 & .326 & 8.924 & .000 \\
\hline Effort & .287 & .018 & .417 & 16.134 & .000 \\
\hline Self-Evaluation & .136 & .015 & .189 & 9.257 & .000 \\
\hline Self-knowledge & .017 & .016 & .031 & 1.042 & .298 \\
\hline Attachment & -.092 & .020 & -.160 & -4.688 & .000 \\
\hline Guidance & .154 & .023 & .407 & 6.605 & .000 \\
\hline Opportunity & .001 & .009 & .004 & .106 & .915 \\
\hline Reassurance & .076 & .014 & .224 & 5.370 & .000 \\
\hline Reliable alli & .001 & .019 & .001 & .030 & .976 \\
\hline Social integ & .075 & .014 & .244 & 5.489 & .000 \\
\hline & $b$. & $\begin{array}{r}\text { a. Depen } \\
\text { Least Squc }\end{array}$ & $\begin{array}{l}\text { ariable: School } \\
\text { gression - Weighted by Bob }\end{array}$ & & \\
\hline
\end{tabular}

Based on the table can be seen the regression equation as follows: ZSchool Engagement $=0.309$ Zinitiative -0.326 ZPersistence +0.417 Effort +0.189 Self-evaluation +0.31 Self-Knowledge - 0.160 Attachment +0.407 Guidance + 0.004 Opportunity for nurturance +0.224 Reassurance of worth +0.001 Reliable alliance -0.244 Social Integration.

This research model shows that there are 8 of the 11 variables that significantly influence school engagement namely initiative, persistence, effort, self-evaluation, attachment, guidance, reassurance of worth, social integration, while the rest of the variables are insignificant. The explanation of the value of regression coefficients obtained on each independent variable is as follows:

\section{Initiative}

The regression coefficient of the initiative is known 0.309 with Sig. 0.000 (Sig. <0.05). It means that initiatives significantly influence school engagement with positive influence, so the higher the initiative the higher the school engagement.

\section{Effort}

The regression coefficient of effort is resulted 0.417 with Sig. 0.000 (Sig. <0.05), it means that effort significantly affects school engagement with positive influence, so the higher the effort the higher school engagement.

\section{Persistence}

The regression coefficient of persistence is known 0.326 with Sig. 0.000 ( $\mathrm{sig}<0.05$ ), it means that persistence significantly affects school engagement with a positive influence, means that the higher the persistence the higher school engagement.

\section{Self-knowledge}

The regression coefficient of self-knowledge is 0.31 with Sig. 0.298 ( $\operatorname{sig}>0.05)$, it means that self-knowledge does not affect school engagement.

5. Self-evaluation

The regression coefficient of self-evaluation is 0.189 with Sig. $0.000(\operatorname{sig}<0.05)$, it means that self-evaluation significantly influences school engagement, so the higher the self-evaluation the higher the school engagement.

\section{Attachment}

The regression coefficient of attachment is -0.160 with Sig. 0.000 ( sig <0.05), it means that attachment significantly affects school engagement with the negative influence, so the higher attachment the lower the school engagement.

\section{Guidance}

The regression coefficient of attachment 0.407 with Sig. 0.000 ( $\mathrm{sig}<0.05$ ), it means that guidance significantly affects school engagement, with positive influence, so the higher the guidance the higher school engagement.

\section{Opportunity for nurturance}

The regression coefficient of opportunity for nurturance is 0.004 with Sig. 0.915 ( $\mathrm{sig}>0.05)$, it means that opportunity for nurturance does not affect school engagement.

\section{Reassurance of worth}

The regression coefficient of the reassurance of worth is 0.224 with Sig. $0.000(\operatorname{sig}<0.05)$, it means that reassurance of worth significantly influences school engagement, so the higher the reassurance of worth the higher the school engagement.

\section{Reliable alliance}

The regression coefficient of reliable alliance is 0.001 
with Sig. 0.976 (sig $>0.05)$, it means that reliable alliance does not affect school engagement.

\section{Social integration}

The regression coefficient of social integration is 0.244 Sig. $0.000(\mathrm{sig}<0.05)$, it means that social integration significantly affects school engagement, so the higher social integration the higher school engagement.

Table 3. Proportion of Variant Each Independent Variable

\begin{tabular}{|c|c|}
\hline Variabel Independent & (Proportion) \\
\hline Initiative & $14.32 \%$ \\
\hline Persistence & $13.94 \%$ \\
\hline Effort & $32.16 \%$ \\
\hline Self-evaluation & $20.18 \%$ \\
\hline Self-knowledge & $5.03 \%$ \\
\hline Attachment & $0.57 \%$ \\
\hline Guidance & $3.48 \%$ \\
\hline Opportunity for Nurturance & $0.91 \%$ \\
\hline Reassurance of Worth & $4.43 \%$ \\
\hline Reliable Alliance & $2.96 \%$ \\
\hline Social Integration & $2.00 \%$ \\
\hline
\end{tabular}

Thus, it can be concluded that there are two variables that have the greatest influence on school engagement, first is effort that has the effect with $32.16 \%$, second is self-evaluation with $20.18 \%$.

\section{Conclusions}

The result of this research shows that self-efficacy, self-concept and social support have significant influence on school engagement, this result is in accordance with some previous research which stated that self-efficacy has a significant effect on school engagement, one of previous research is done by Caraway, Tucker, Reinke and Hall which stated that self-efficacy has a positive relationship to school engagement, the results of his research revealed that the more confident a person about his ability, the more he/she will have good grades, and more engage in some aspects of school activities[6].

The initiative dimension of self-efficacy variable has a significant influence, means that the higher the initiative the higher the school engagement. According to Bosscher and Smit (1998) initiative is one's willingness to behave first. This dimension refers to the individual's behavior to be ready for any situation. Some individuals believe that they are only capable of producing certain behaviors in certain circumstances [10]. Meanwhile there are also individuals who are able to adapt to any conditions. Thus if the individual has a high initiative he will have the willingness to behave actively, engage in various activities and ready to face any conditions, so that the individual will be more engaged in learning activities, in this case if student of Pesantren Assa'adah has high initiative, then they will be more likely to be involved in learning activities at school, and ready to face all life situations.

Meanwhile other dimension that has a significant effect on school engagement was effort, this variable affect school engagement with variant proportion $32.16 \%$, according to Bosccher and Smit (1998) effort is a willingness to be perfect, this is related to the belief of someone towards challenges[10] The variety views of one's belief on doing a task are different, perhaps one assumes a task as simple, intermediate or even difficult tasks, but one considers a task was difficult, while others may not feel that way. Individuals who have high effort will be more challenged to do new things or difficult things, this is what causes them to be more involved in the learning process, because they feel challenged with a strong conviction to solve it. Thus someone who has high effort, then has high school engagement, because if the individual has the willingness to strive in completing certain tasks and this is related to the belief in facing the challenge, then he will always be ready to deal with any situation and will feel challenged to finish difficult tasks, so that the individual will involve in various learning activities.

Then the persistence dimension of self-efficacy is known which have positive effect to school engagement. According to Boscher and Smit (1998) persistence is perseverance to face adversity [10]. This dimension relates to the persistence of a person in facing adversity. A person who has a strong belief in his ability to do a task will continue to survive in his efforts to overcome obstacles or challenges. Thus people who have high persistence will have high school engagement, either in doing the tasks or in facing difficult situations, in other hand someone who less belief will more easily disengage. The level of one's self-efficacy also determines one's ability to complete tasks, including the ability to choose which tasks to complete first, the seriousness of the effort, persistence, and enthusiasm for the task which is followed by positive feelings. Goetz et. al (2010) revealed that self-efficacy can influence the way of thinking, acting and emotion directly. So that individuals who have high self-efficacy followed by the way of thinking, acting and positive emotions, then affect the school engagement [7].

Furthermore, the results of this study which explains that self-evaluation dimension has significant influence on school engagement, is related to previous research which is conducted by Singh, Chang, and Dika (2010) to 1,157 high school students in three western regions of Virginia United States, results of this study explain that the concept of self-concept is closely related to feelings of happiness during learning (enjoyment of learning), then increase involvement in learning (school engagement)[14]. Self-concept is also known as one of strong influence on student persistence in completing the task, conclusion from this researches that self-concept influence school engagement and improve learning achievement with 
different quantity. It is known that the results of the self-evaluation study have a variance proportion of $20.18 \%$, which is the second largest contribution affecting school engagement. This explains that the more students have the ability to evaluate themselves, the more involved they will be in learning, meaning that when a person is more aware of him or her less than the mastery of learning materials, he/she will try to do things that can improve his/her ability, eventually makes them engage in learning.

Overall the result of this research specifically about the effect of social support to school engagement is suitable with some previous researches, some related research who explain that social support has a significant effect on school engagement is done by Wang and Eccles to 1,792 student from senior junior high school to senior high school, the research is aimed to examine the influence of social support on the three dimensions of school engagement in the middle to upper secondary level, results of his research reveals that students who have high social support tend to have good adaptation and high achievement motivation[20]. Social support which is derived from teachers can foster a sense of loving school and improve achievement [17], whereas students with positive social support from peers have a high degree of emotional and behavioral engagement [18].

Guidance is one of social support dimension that has a positive and significant influence on school engagement means that the higher guidance, the higher school engagement. According to Cutrona and Russell (1987) guidance is social support in the form of a working relationship or social relationship that allows people to get the information, advice, or advice needed to meet the needs and overcome the problems faced[19]. This type of social support comes from teachers, ustaz/teacher in society, elderly figures and also parents. Thus if students in boarding school (pesantren) have social support such as guidance then they will get guidance, advice or support from teachers, caregivers. When they face learning difficulties, they will feel guided, feel cared for, and feel perceived, so that they will become more involved in the learning process.

The result of another social support dimension that has a positive influence and significant is the reassurance of worth, means that the higher reassurance of worth, the higher school engagement. Referring to Cutrona and Russell (1987) reassurance of worth is a kind of social support whereby a person gets recognition of his or her skills and rewards from others or institutions[19]. Sources of social support of this kind can come from families or institutions or schools/organizations. If student has the kind of social support reassurance of worth means that they will get recognition for their ability, it makes them feel needed and appreciated by friends, organizations, institutions/schools. This creates confidence and encourages them to be actively involved in school activities.
Relating to the subsequent dimensions of social support that have a positive and significant impact to school engagement is social integration. This type of social support allows someone to gain feeling of belonging to a group that enables him/her to share interests, concerns and engage in recreational activities simultaneously and can relieve feelings of anxiety even for a moment. Social integration support can be derived from various activities of extracurricular groups or groups with similar interests and hobbies. Students who have high social integration are usually incorporated into some extracurricular activities or study groups, hobbies and sports that enable them to share interests, attention, and engage in recreational activities.

Furthermore, the hypothesis test results from social support variables known that attachment has a negative effect to school engagement. It means that the higher attachment the lower school engagement. According to Cutrona and Russell (1998) social attachment support is a type of social support that enables a person to gain emotional attachment so as to create a sense of security for the recipient. People who receive this kind of social support feel peaceful, and secure which is shown by a calm and happy attitude. This source of social support is most often and commonly obtained from spouses, or family members, parents, close relatives and close relationships [19]. This is reason why student who receive more attachment from their parents or relatives will feel unhappy to live in pesantren, they are always want to close with their parent unfortunately makes them bored. Students who do not wholeheartedly live and study in pesantren tend not to engage in learning, this can lead to rebellious behavior in the form of disobeying regulation.

\section{Suggestions}

Because this research is focused on boarding school students (santri) it can be suggested for further research can be done on non-boarding schools. Allegedly, with differences in characteristics between dormitories and non-dormitories, different research findings will be found. For further research is suggested to examine the impact of school engagement on learning outcomes.

Related to initiative dimension, several suggestions are expected to be applied in learning activity, for the teacher should strengthen student's self-confidence, and should motivate students to be ready to take initiative, to increase the confidence of students, teachers can do it by rewarding their achievements, can be an appreciation of the behavior of student initiatives, positive feedback or constructive advices. Besides that, parents are suggested to encourage students' self-efficacy; parents can do it by giving attention, advice, motivation, and not spoiling them during family visits. By giving advice, attention and motivation they will feel valued and loved, thus making them always eager in learning and completing schoolwork. Parents are also 
advised to not only judge results but also appreciate the learning process. If students gain reinforcement about the importance of self-confidence and gain appreciation for their achievements, this is expected to improve students' sense of confidence.

Associated with self-efficacy variable of the effort dimension, it is suggested to the teacher, to give understanding to the students that they are able to do difficult task in learning. To improve student effort, teachers can provide tasks with a level of difficulty tiered, starting from the easiest level to the most difficult. It is expected that students are not easily desperate in doing the task, if the students are directly confronted with the most difficult tasks, when they cannot do it they will easily give up. In addition, in every assignment, teachers are expected to provide intensive mentoring to students, so that students can ask the teacher when having difficulty in completing the task. While for parents it is advisable to appreciate all forms of student achievement outcomes. Because students have views and beliefs about different tasks, perhaps a person is confined to simple, intermediate or even difficult tasks. Some assume a task is difficult, while others may not feel that way. Hopefully, when students get appreciation from parents for all their efforts in learning, students will have high effort.

Regarding self-efficacy variables of persistence dimension, it is suggested to the teacher, in order to give reinforcement to the students that they can continue to persevere in facing various tasks or difficulties, it can be done by providing guidance when students are in trouble or difficulty, not only appreciate the results, but also the process. While advice to the parents, to improve the persistence of students, it can be done by providing support in the form of advice and keep maintaining good communication. So that, students can share and tell about the difficulty that they face in learning.

The other suggestion comes from self-evaluation dimension, to improve self-evaluation it can be suggested to the teachers and parents to be able to provide reinforcement of student self-concept. Students with high self-concept will have high school engagement. Teachers and parents can provide knowledge about the procedures for self-evaluation, such as introspection of everything that has been done or provide an understanding of how to recognize self-potential.

Next suggestion comes from social support variable of attachment dimension, to deal with this variable it is suggested to the parents, in order to give understanding to their son and daughter that living in pesantren will not reduce the parental affection towards them. Living and studying in pesantren does not mean loved and alienated by the family. Parents and teachers are expected to provide guidance to students about the meaning of independence. So that students will feel calm and happy even though they live far from parents or relatives. While the teacher is advised to provide comfort and feel at home for students in pesantren, teachers can hold positive-activities that can involve students in it, such as extracurricular activities related to interests and talents, scout activities, nature lovers and others.

Based on the result of guidance dimension, it is advised for teacher and parents to keep good communication with their son/daughter, it is expected by keeping a good communication they will open and share about the problem that they face. When students get high guidance then they will feel cared for and feel valuable so that, it will lead them to high engagement in learning.

Regarding to the reassurance of worth, it can be suggested to the teacher and parents to always appreciate every student achievement, appreciate the students' ability, and avoid the sentences that can dampen their spirit. Because student high school are the times when they need recognition of their existence. Becomes important for them to get recognition and respect for their skills, the recognition and appreciation will be something that can improve their confidence and improve school engagement. The last suggestion comes from social integration dimension, regarding to improve student engagement based on social integration research result, it can be suggested to schools, teachers and parents to encourage students to participate in many extracurricular groups activities related to their hobbies, and interests. So that, students will get a sense of belonging from a group that allows them to share their interests, concerns and engage in positive activities, thus eliminating their boredom and anxiety during their stay at the pesantren.

\section{REFERENCES}

[1] J. D. Finn, School Engagement \& Students at Risk. 1993.

[2] K. L. Hyde et al., "The Effects of Musical Training on Structural Brain Development: A Longitudinal Study," Annals of the New York Academy of Sciences, vol. 1169, no. 1, pp. 182-186, Jul. 2009.

[3] C. Furrer and E. Skinner, "Sense of relatedness as a factor in children's academic engagement and performance.," Journal of Educational Psychology, vol. 95, no. 1, pp. 148162, 2003.

[4] J. A. Fredricks, P. C. Blumenfeld, and A. H. Paris, "School Engagement: Potential of the Concept, State of the Evidence," Review of Educational Research, vol. 74, no. 1, pp. 59-109, Mar. 2004.

[5] A. Abdurrahman, "Private Communication," 16-Oct-2016.

[6] K. Caraway, C. M. Tucker, W. M. Reinke, and C. Hall, "Self-efficacy, goal orientation, and fear of failure as predictors of school engagement in high school students," Psychol. Schs., vol. 40, no. 4, pp. 417-427, Jul. 2003.

[7] J. L. Goetz, D. Keltner, and E. Simon-Thomas, "Compassion: An evolutionary analysis and empirical review", 
Psychological Bulletin, vol. 136, no. 3, pp. 351-374, 2010.

[8] D. Stipek, "Context Matters: Effects of Student Characteristics and Perceived Administrative and Parental Support on Teacher Self-Efficacy," The Elementary School Journal, vol. 112, no. 4, pp. 590-606, Jun. 2012.

[9] A. M. Dotterer and K. Lowe, "Classroom Context, School Engagement, and Academic Achievement in Early Adolescence," J Youth Adolescence, vol. 40, no. 12, pp. 1649-1660, Dec. 2011.

[10] R. J. Bosscher and J. H. Smit, "Confirmatory factor analysis of the General Self-Efficacy Scale," Behaviour Research and Therapy, vol. 36, no. 3, pp. 339-343, Mar. 1998.

[11] B. Bracken, "Positive self-concepts.," 2009, pp. 89-106.

[12] H. W. Marsh, "Self-concept theory, measurement and research into practice: The role of self-concept in educational psychology," 2006.

[13] R. J. Shavelson, J. J. Hubner, and G. C. Stanton, "Self-Concept: Validation of Construct Interpretations," Review of Educational Research, vol. 46, no. 3, pp. 407441, Sep. 1976.

[14] K. Singh, M. Chang, and S. Dika, "Ethnicity, self-concept, and school belonging: effects on school engagement," Educ Res Policy Prac, vol. 9, no. 3, pp. 159-175, Oct. 2010.

[15] J. D. Campbell, P. D. Trapnell, S. J. Heine, I. M. Katz, L. F. Lavallee, and D. R. Lehman, "Self-concept clarity: Measurement, personality correlates, and cultural boundaries.," Journal of Personality and Social Psychology, vol. 70, no. 1, pp. 141-156, 1996.

[16] M.-T. Wang and R. Holcombe, “Adolescents' Perceptions of School Environment, Engagement, and Academic Achievement in Middle School," American Educational Research Journal, vol. 47, no. 3, pp. 633-662, Sep. 2010.

[17] R. W. Roeser, J. S. Eccles, and A. J. Sameroff, "Academic and emotional functioning in early adolescence: Longitudinal relations, patterns, and prediction by experience in middle school," Dev Psychopathol, vol. 10, no. 2, pp. 321-352, Jun. 1998.

[18] P. Garcia-Reid, "Examining Social Capital as a Mechanism for Improving School Engagement Among Low Income Hispanic Girls,” Youth \& Society, vol. 39, no. 2, pp. 164 181, Dec. 2007.

[19] C. E. Cutrona and D. W. Russel, "The Provisions of Social Relationships and Adaptation to Stress," Advances in Personal Relationships, vol. 1, pp. 37-67, 1987.

[20] M.-T. Wang and J. S. Eccles, "Social Support Matters: Longitudinal Effects of Social Support on Three Dimensions of School Engagement from Middle to High School: Social Support," Child Development, vol. 83, no. 3, pp. 877-895, May 2012.

[21] G. L. Macklem, "Boredom in the classroom: Addressing student motivation, self-regulation, and engagement in learning," vol. 1. Springer, 2015.

[22] A. Aritzeta, N. Balluerka, A. Gorostiaga, I. Alonso-Arbiol, M. Haranburu, and L. Gartzia, "Classroom emotional intelligence and its relationship with school performance," European Journal of Education and Psychology, vol. 9, no.
1, pp. 1-8, Jun. 2016.

[23] A. F. Alves, C. M. A. Gomes, A. Martins, and L. da S. Almeida, "Cognitive performance and academic achievement: How do family and school converge?" European Journal of Education and Psychology, vol. 10, no. 2, pp. 49-56, Dec. 2017.

[24] A. Fernández-Zabala, E. Goñi, I. Camino, and L. M. Zulaika, "Family and school context in school engagement," European Journal of Education and Psychology, vol. 9, no. 2, pp. 47-55, Dec. 2016.

[25] A. D. Strati, J. A. Schmidt, and K. S. Maier, "Perceived challenge, teacher support, and teacher obstruction as predictors of student engagement," Journal of Educational Psychology, vol. 109, no. 1, pp. 131-147, 2017. 